\title{
ОСОБЛИВОСТІ ОРГАНІЗАЦІЇ САМОСТІЙНОЇ РОБОТИ СТУДЕНТІВ- ПЕРШОКУРСНИКІВ МЕДИЧНОГО УНІВЕРСИТЕТУ: ТРУДНОЩІ ТА ШЛЯХИ ЇХ ВИРІШЕННЯ
}

\author{
І. Д. Сиротинська
}

Івано-Франківський національниймедичний університет

\author{
PECULIARITIES OF INDEPENDENT WORK ORGANIZATION OF \\ FIRST-YEAR STUDENTS OF MEDICAL UNIVERSITY: CHALLENGES \\ AND TREIR SOLUTIONS
}

I. D. Syrotynska

Ivano-Frankivsk National Medical University

\begin{abstract}
У статті розглянуто актуальні проблеми в організації самостійної роботи студентів за умови впровадження кредитномодульної системи навчання. Авторами розглянуто ряд проблем щодо організації самостійної роботи студентів першого курсу при вивченні дисципліни “Медична хімія”, та запропоновано шляхи і методи їі удосконалення.
\end{abstract}

The article adduces the current problems in the organization of students' independent work in the condition of introduction of credit-transfer system of education. The authors discussed a number of problems concerning the organization of independent work of first-year students in the study course "Medical Chemistry", and offered the ways and methods of its improvement.

Вступ. На сучасному етапі розвитку світового суспільства освіта стає найважливішим елементом соціальної сфери держави. Значення освіти в сучасному життілюдини зростає, оскільки вона відіграє вирішальну роль як у соціальному, так і в економічному розвитку країни. Нагальна потреба в постійному підвищенні рівня знань привела до появи такого цікавого феномену в суспільному житті, як самоосвіта та безперервна освіта [1]. Отже, індивідуальний розвиток людини, особистості за таких умов $\epsilon, з$ одного боку, основним показником прогресу, а з другого - головною передумовою подальшого розвитку суспільства $[2,3]$.

Майбутні випускники шкіл, ліцеїв та гімназій стоять перед складним вибором - вибором майбутньої професії, на який вони покладають велику надію забезпеченого життя. Отримання бажаної спеціальності безпосередньо пов' язане з отриманням якісної вищої освіти, яка б дозволила працевлаштовуватися за обраним фахом. Вступивши на перший курс такого омріяного для більшості медичного ВНЗ, першокурсники стикаються з безліччю нових видів навчальної діяльності, яких не було у школі. I саме сумлінне та якісне виконання поставлених перед студентами завдань, починаючи 3 першого семестру навчання, дає можливість здобути престижний фах і бути конкурентоспроможними на ринку праці.
Приєднання України до Болонського процесу є метою реформування і удосконалення процесу підготовки висококваліфікованих фахівців, створення оптимальних умов та прогресивних методів навчання і контролю знань студентів [1-5, 7]. За сучасними умовами Болонської системи велика увага приділяється самостійній роботі студентів $[1,5,6]$. Вона $€$ основним засобом оволодіння навчальним матеріалом у час, вільний від обов' язкових навчальних занять, i $€$ невід'ємною частиною процесу підготовки фахівця. Метою самостійної роботи студента $€$ набуття додаткових знань 3 дисципліни, перевірка отриманих знань на практиці, вироблення певних дослідницьких та фахових вмінь і навичок. Між тим необхідною організаційною передумовою здійснення самостійної роботи є забезпечення різноманітності форм отримання студентами навчальної інформації, що відкриє перед кожним можливість максимально ефективного засвоєння матеріалу і найефективнішим використанням характерного йому типу пам'яті та мислення. Особливе місце самостійна робота займає у підготовці майбутнього лікаря [7]. Адже мова йде про підготовку спеціаліста, який повинен бути готовим до прийняття виваженого самостійного рішення в складній, інколи непередбачуваній ситуації. 
Основна частина. Метою статті став аналіз організації самостійної роботи студентів першого курсу медичних університетів та їі важливої ролі в системі підготовки висококваліфікованих фахівців на прикладі Івано-Франківського національного медичного університету 3 досвіду кафедри біологічної та медичної хіміі. Розглянуто основні труднощі, що перешкоджають ефективній самопідготовці першокурсників, та шляхи їх подолання.

Згідно з Законом про вищу освіту, самостійна робота студентів є однією з основних форм навчального процесу ВН3 [1, 2]. Це ще одна особливість навчання, 3 якою стикаються на першому курсі студенти, вчорашні школярі. Звичайно, в школі теж було приділено достатньо уваги самостійній роботі, наприклад реферативній, пошуковій тощо. Але відповідні види робіт виконуються тільки кращими школярами, з високим рівнем знань і бажанням самоосвіти. В університетах, натомість, самостійна робота є обов'язковою для всіх студентів. 3 перших занять одразу стає помітним поділ студентського колективу на кілька груп залежно від рівня шкільної підготовки. Є студенти, їх близько 10-15 \% у групах, що в змозі успішно навчатися і виконувати різні види самостійної роботи якісно та сумлінно. Більша ж частина молодих людей мають деякі труднощі 3 навчанням, відповідно часу на самостійну роботу іноді недостатньо, їх близько 60 \%. I звичайно, у кожному 3 вищих навчальних закладів є студенти, що мають істотні проблеми 3 навчанням, деякі предмети їм даються важко, очевидно, на самостійну роботу у них вже не вистачає сил, а подекуди і просто бажання та мотивації.

Слід зазначити, що студенти першого курсу стикаються з рядом чинників, які заважають здійснювати самостійну роботу в повному обсязі. Серед них слід відзначити такі, як:

- невміння планувати навчальну роботу та свій час загалом;

- втомлюваність, зумовлена великим навантаженням та стресами;

- труднощі у пошуку необхідної інформації, відсутність комп'ютера, інтернету, інформаційних ресурсів [6];

- недостатність методичного керівництва викладача [1];

- невміння опрацьовувати та фіксувати інформацію;

- та чи не основний на сьогодні чинник - незацікавленість у предметах, які вивчаються, i, зрештою, небажання відвідувати заняття та консультації з деяких дисциплін.
Крім того, велика частина студентства починає самостійне життя у гуртожитку, де з'являється ряд побутових незручностей, можливі психологічні конфлікти з сусідами по кімнаті тощо.

Ситуація значно покращується на старших курсах, де майбутні лікарі вивчають клінічні дисципліни, що $\epsilon$ необхідними для одержання високої кваліфікації. 3'являється усвідомлення та розуміння важливості самостійної роботи та й роботи над собою загалом.

Відповідно до умов кредитно-модульної системи навчання організація самостійної роботи покладена на викладача через систему домашніх завдань, постановки проблемних запитань, підбору ситуаційних вправ за певним розділом курсу. Головним завданням для викладача першого курсу є роз' яснення важливості самостійної роботи для успішного засвоєння матеріалу та подальшого складання підсумкових модульних контролів 3 дисципліни. Слід постійно наголошувати на основних розділах, мотивувати та формувати зацікавлення до предмета в першокурсників. Обов' язковим є залучення всіх студентів групи до систематичного і продуктивного виконання самостійного навчання. Важливим є і постійний контроль над виконанням поставлених завдань. Оцінка за виконану роботу повинна бути об' єктивною і входити до суми балів поточного контролю. Студент має чітко усвідомлювати, що його непідготовленість до практичних, лабораторних чи семінарських занять може зашкодити успішному складанню модульного контролюз дисципліни.

Звісно, молода людина відчуває підвищену відповідальність за результати власної навчальної діяльності, а також мотивацію набувати нові знання протягом всього викладання дисципліни, а не вивчати весь матеріал підручника у переддень модульного контролю. Також підвищення систематичності та якості аудиторної й самостійної роботи студента сприяє об' єктивності оцінювання знань.

Види занять для самостійної роботи залежать від особливостей курсу чи спецкурсу. Зокрема, основними дисциплінами для студентів першого курсу медичних вузів є анатомія, гістологія, медична хімія, медична біологія, медична фізика, психологія, історія України і ряд інших. Слід зазначити, що основний час на підготовку у студентів займають анатомія та гістологія, адже дані дисципліни вимагають ідеальної теоретичної підготовки та є основними для подальшого здобування медичної освіти. Натомість, інші дисципліни тежє важливими, алеїх значимість для здобуття фаху лікаря є недооціненою. Спільним для усіх предметів є необхідність пошуку та реферу- 
вання наукової літератури, виконання та аналіз ситуаційних вправ, опрацювання навчального матеріалу та складання структурно-логічних схем до тем та розділів. 3 такими видами діяльності студенти справляються більш-менш успішно. Натомість, для окремих предметів необхідним є виконання певної практичної роботи та розв' язування розрахункових задач. Саме у цих видах діяльності успіхи студентів різко знижуються. Адже не усі абітурієнти мають високі математичні та аналітичні здібності. Так, існують суттєві проблеми у вивченні дисципліни "Медична хімія”. Хоча обов' язковим для усіх абітурієнтів $\epsilon$ складання зовнішнього незалежного оцінювання 3 хіміі. Для полегшення успішного виконання самостійної роботи та якісної підготовки до навчання викладачами кафедри біологічної та медичної хімії щороку оновлюються методичні матеріали, розробляються завдання тестового контролю, а також підготовлено науково-методичні посібники.

Відповідно до положень кредитно-модульної системи виконання студентом самостійної роботи оцінюється певною кількістю балів до поточного модульного контролю. Іноді, для студента 3 низьким рівнем знань, це ледь не єдиний спосіб набрати визначену мінімальну кількість балів для складання підсумкового модульного контролю. Для такої категорії першокурсників на кафедрі організовуються консультації та індивідуальна робота викладачів зі студентами. Тобто самостійна робота, не виконана вчасно, може бути доопрацьованою. В протилежному ж випадку студент буде недопущений до складання модульного контролю.

Окрему увагу на кафедрі приділяють студентам, які випереджують інших у знаннях, беруть участь в олімпіадах, наукових конференціях, науковій роботі, догляді за досліджуваними тваринами тощо. Переважно це $\epsilon$ випускники гімназій, ліцеїв з відповідним профілем або школярі, які з дитинства прагнули стати медиками. Для них вводиться певна кількість балів під назвою “індивідуальна робота”, що сумується з бала-

\section{Лiтература}

1. Грицюк Л. К. Організація самостійної роботи студентів у навчальному процесі вищого навчального закладу / Л. К. Грицюк, М. В. Сірук // Науковий вісник Волинського національного університету імені Лесі Українки. - 2011. № 17. - С. 9-14.

2. Закон України про вищу освіту: наук.-практ. комент. / за заг. ред. В. Г. Кременя. -К. : СДМ-Студіо, 2002. - 328 с.

3. Модернізація вищої медичної освіти в контексті Болонської конвенції - ідея, мета, реалії / В. М. Мороз, ми, отриманими за дисципліну. Відповідно, підвищується рейтинг таких активних молодих людей і прищеплюється мотивація до нових звершень та подальших наукових відкриттів. Зокрема, щороку на кафедрі біологічної та медичної хімії виконуються науково-дослідні проекти за участю студентів першого курсу. Здобутки молодих науковців оцінено призовими місцями на тематичних наукових конференціях.

Хоча, на жаль, як свідчать дані досліджень, студенти надто мале значення приділяють самому значенню самостійної роботи $[1,6]$. Тобто сучасна молодь розуміє, що для отримання професії потрібно багато і сумлінно вчитися на практичних заняттях, відвідувати лекції і семінари, натомість самостійна робота не є обов' язковою для виконання.

Висновок. Таким чином, самостійна робота студентів у вищому навчальному закладі $є$ необхідною передумовою для отримання необхідних знань, вмінь і навиків професії лікаря. Сучасний високомпетентний фахівець повинен бути освіченим, мобільним, мати загальну та професійну культуру та здатним до постійної самоосвіти, самовдосконалення та підвищення рівня знань у своїй галузі діяльності.

Впровадження кредитно-модульної системи навчання сприяло значній оптимізації навчального процесу, адже увага акцентується на активній та індивідуальній діяльності студента, оперативному проміжному контролі та своєчасному коректуванні рівня засвоєння знань. Також створено оптимальні умови для раціонального і ефективного засвоєння знань i вмінь, активізації пізнавального процесу, стимулювання студентів до систематичної самостійної навчальної діяльності, та використання прогресивних методів навчання і контролю знань студентів.

Проблемними питаннями залишаються розвиток $\mathrm{i}$ підтримання належної мотивації майбутніх лікарів до навчання, оптимізація самостійної роботи студентів та відведення належної уваги роботі викладача, що є основним чинником у мотивації до навчання та допомозі студенту.

Ю. Й. Гумінський, Л. В. Фоміна [та ін.] // Медична освіта. 2012. - № 2. - С. 42-45.

4. Організація навчального процесута котроль його якості в умовах застосування кредитно-модульної системи навчання на клінічних кафедрах вищих медичних навчальних закладів України / І. С. Вітенко, Г. В. Дзяк, Я. С. Березницький [та ін.] // Медична освіта. - 2010. - № 1. - С. 41-44.

5. Вакарчук I. О. Вища освіта України - європейський вимір: стан, проблеми і перспективи / І. О. Вакарчук // Вища 
школа. -2008. - № 3. - С. 3-18.

6. Шимко І. Проблеми організації самостійної роботи у вищій школі / І. Шимко// Рідна шк. - 2005. -№ 8. - С. 34-35.

7. Ефективність поєднання традиційних форм навчання iз засадами Болонського процесу у доклінічній підготовці лікарів / М. М. Багрій, Н. М. Воронич-Семченко, О. Г. Попадинець [та ін.] // Галицький лікарський вісник. -2010. - Т. 17, № 1. - С. 89-91. 